\title{
The “Three National Treasures of Silla (新羅三寶)" and Their Transfer: The Symbol of the Unification of the Koryŏ Dynasty
}

Bo-kwang Kim*

\section{Introduction}

In 920, when a delegation of envoys from the Kingdom of Silla visited T'aejo Wang Kŏn of Koryŏ, Wang Kŏn asked about the existence of the "three national treasures of Silla." Then in 937, a year after Koryŏ unified the Later Three Kingdoms into one country, Kim Pu, the last king of Silla, handed over one of the three treasures: the jade belt bestowed by the heavens (ch'ónsa okdae, hereafter the jade belt), to T'aejo. Since then the three national treasures of Silla (Silla sambo) became the treasures of Koryŏ.

Stories about the three treasures (sambo) appear in the Memorabilia of the Three Kingdoms (Samguk yusa, hereafter Memorabilia), one of the oldest books in Korea that contains stories and accounts of historical events from the Three Kingdoms era. Buddhism is a major theme in the book, which even contains information on the introduction and propagation of Buddhism in Silla with the support of the government. Therefore the records on the three national treasures demonstrate the relationship between Silla and Buddhism. ${ }^{1}$

* Lecturer, Department of History and Culture, Daejeon University.

1 Robert E. Buswell Jr. ed., Currents and Countercurrents: Korean Influences on the 
I would like to call attention to the fact that the transfer of the "three national treasures of Silla" from Silla to Koryŏ occurred in 937. Kim Pu, also known as Kyŏngsun, the last king of Silla, surrendered to Koryŏ in 935, which means all of Silla's assets, including its treasures, were frozen and turned over to Koryŏ. However, Kim Pu only presented the jade belt to T'aejo of Koryŏ in 937, a year after the Later Three Kingdoms were unified in 936. Therefore, the timing of the transfer of the jade belt is politically significant. I believe that the transfer of the jade belt was not simply a symbolic event that signified the change of dynasties from Silla to Koryŏ but rather a transfer of the legitimacy of power from Silla to Koryŏ in the history of Korea.

From this perspective, I would like to delve into the historical significance of the transfer of the jade belt. To this end, I will first examine each of the three national treasures of Silla, including the jade belt, as well as their emergence in history. Next, I will attempt to uncover the identity of the "king of Koryŏ," who appears in the stories demonstrating the miraculous power of the three national treasures of Silla. Lastly, I will explore the transfer process of the transfer of the three national treasures of Silla. Through this study, I hope to shed light on the significance of the transfer of the treasures, which took place in 937, or in other words, the historical legitimacy of the Koryŏ dynasty in the history of Korea.

East Asian Buddhist Traditions. (Honolulu: University of Hawai'i, 1993); Sem Vermeersch, "Representation of the Ruler in Buddhist Inscriptions of Early Koryo," Korean Studies 26-2 (2002); Robert E. Buswell Jr., "Korean Buddhist Thought in East Asian Context," Pulgyo Hakbo 60 (2011): 97-231; Ryan Bongseok Joo, "Buddhism in Korean History." in The Wiley Blackwell Companion to East and Inner Asian Buddhism, ed. Mario Poceski (Chicester: Wiley Blackwell, 2014). 


\section{Emergence of the "Three National Treasures of Silla" and its Significance}

In October 920, T'aejo Wang Kŏn of Koryŏ asked Kim Ryul, who visited Koryŏ as an envoy from Silla, about the "three national treasures of Silla." He said, "I heard that there are three treasures in Silla- a sixteenfoot bronze Buddha statue (changnyukjonsang) and a nine-tiered pagoda (kuch'üngt'ap) at Hwangnyong Temple, and a sacred belt. I know the bronze Buddha statue and the nine-tiered pagoda are still there, but what about the sacred belt?" ${ }^{2}$ This conversation revealed that there were three treasures in Silla: the sixteen-foot bronze Buddha statue and the ninetiered pagoda at Hwangnyong Temple, and a sacred belt. Records indicate that the sixteen-foot bronze Buddha statue was built in the late sixth century, during the reign of King Chinhŭng; the sacred belt, or the jade belt appeared in the first half of the seventh century, during the reign of King Chinp'yŏng; and the nine-tiered pagoda of Hwangnyong Temple, in the mid-seventh century, during the reign of Queen Sŏndǒk. ${ }^{3}$

The background and the process of the construction of the first treasure, the sixteen-foot bronze Buddha statue at Hwangnyong Temple, is described in detail in the chapter titled "Changnyukjonsang" (sixteen-foot bronze Buddha statue). ${ }^{4}$

2 Samguk sagi 12, Annals of Silla 12, January of the 5th year (921) of Kyŏngmyŏngwang. Kim Ryul went to Koryŏ in October 920 (Ibid.).

3 Since Silla Sambo has already been analyzed in detail, I will briefly introduce these in this article. In particular, the original text of Memorabilia has been translated into English and other foreign languages. There are three things I have referred to: Ilyeon, SAMGUKYUSA: Legenden \& Wundergeschichten aus den drei Königreichen Koreas, trans. Brandt e. K (Germany: EB-VERLAG, 2005); Ilyeon, Overlooked Historical Records of the Three Korean Kingdoms, trans. Kim DalYong (Seoul, Korea: Jimoondang, 2006); Ilyon, Legends and History of the Three Kingdoms of Ancient Korea, trans. Ha Tae-hung \& Grafton Mintz (Seoul, Korea: Silk Pagoda, 2006).

4 Memorabilia 3, Tapsang 4, Changnyukjonsang. 
The chapter consists of four main parts. The first part tells the story of a dragon appearing from the plot of land that King Chinhŭng had set aside to build a new palace. Inspired by the appearance of the dragon, the king built a temple instead of a palace and called it Hwangnyong Temple, meaning the "temple where a dragon appeared." The construction of the temple was finished in 569. The second part recounts the process of the creation of the bronze Buddha statue. After the temple was completed, a huge vessel carrying the necessary materials to build a statue of Buddha appeared in the sea of Silla. According to the records, the ship had been sent away by the Indian Emperor Ashoka after he failed to build statues of Buddha in the hopes that it would reach a place where the statues could be built. Upon finding the ship, Silla cast a sixteen-foot bronze statue of Buddha and two statues of bodhisattvas in either 573 or 574 . The third part details the event in which the sixteen-foot bronze statue shed tears, prophesying the death of King Chinhŭng, and the fourth part returns to the perspective of Iryŏn, the compiler of the Memorabilia, who explains that the Buddha statue and the two bodhisattva statues have vanished, leaving only a small statue of Buddha behind.

Interestingly, the Memorabilia emphasizes that the creation of the sixteen-foot bronze Buddha statue was something that Ashoka of India had been unable to accomplish - the Memorabilia describes that Ashoka attempted but failed to create three statues of Buddha and bodhisattvas and eventually decided to send the materials to a place where someone would be able to create the statues. However, considering that Ashoka died in 232 BCE, it is simply unrealistic and impossible for the ship he had sent away to have appeared in the sea of Silla about 800 years later. There is a Chinese legend that also tells the story of Ashoka and Buddha statues, and it seems that this story had been influenced by the same legend from China. ${ }^{5}$ Nonetheless, this story brings together Emperor Ashoka, known as a

5 Le-na Kim, "Hwangyongsa ŭi Changyukjonsang gwa Silla ŭi A'yukwangsang-gye Bulsang,"'(The Lost Hwangyong-sa Statue of a Buddha Made after the King Asoka Image) Chin-tan Hakpo $46 \cdot 47$ (1979): 56. 
chakravartin (ancient Indian term for an ideal universal ruler) and the guardian of Buddhism, and King Chinhŭng, intimating a close relationship between Silla and Buddhism, as well as between King Chinhŭng and Buddhism. $^{6}$

The second treasure of Silla was the jade belt the heavens bestowed to King Chinp'yŏng. ${ }^{7}$ In 579, the year King Chinp'yŏng ascended the throne, the heavens sent an envoy to Silla and presented a jade belt to King Chinp'yŏng. It was said that King Chinp'yŏng wore the jade belt when he performed rites to the heavens as well as for national rites called Great Rites (taesa, 大祀). This entry is followed by the story of a "king of Koryŏ" who was planning on conquering Silla. Upon learning about the existence of the three national treasures including the jade belt, the "king of Koryŏ" decided against attacking the kingdom.

The entity that bestowed the jade belt to Chinp'yŏng is sometimes considered Buddha, in relation to Buddhism, ${ }^{8}$ and other times it is understood to have derived from Silla's own concept of the heavens. ${ }^{9}$ It is important to note that Chinp'yŏng succeeded King Chinji, who was ousted for his "chaotic governance and lust for women." In this context, it is highly likely that the story of the jade belt that the heavens bestowed on Chinp'yŏng was created for the political purpose of legitimizing Chinp'yŏng's ascension to the throne and strengthening sovereign power. $^{10}$

The last of the three national treasures was the nine-tiered pagoda of Hwangnyong Temple, built during the reign of Queen Sŏndŏk. The entry in the Memorabilia regarding the pagoda can be largely divided into three

6 Sang Hyun Kim, "Silla Sambo ŭi Sŏngrip gwa gŭ Ǔiŭi," Dongguk Sahak (The Dongguk Historical Review) 14 (1980): 55-57.

7 Memorabilia 1. Ki'i 1, The jade belt bestowed by the heavens (ch'ónsa okdae).

8 Kim, "Silla Sambo ŭi Sŏngrip gwa gŭ Ǔiŭi," 59.

9 Miha Chai, "Chŏnsa Okgae wa Hŭk Okdae," Kyung Hee Sahak (The Historical Review of Kyung Hee University) 24 (2006): 29-30.

10 Kim, "Silla Sambo ŭi Sŏngrip gwa gŭ Ǔiŭi," 59; Chai, "Chŏnsa Okgae wa Hŭk Okdae," 30-31. 
parts. The first part describes the story of a Buddhist monk named Chajang. In 636, Chajang traveled to Tang China to further his studies in Buddhism. During his travels through China, he met a divine man. In their conversation, Chajang expressed his concerns over the affairs in Silla, which suffered attacks from Koguryŏ and Paekche. The divine man then revealed himself to Chajang as the father of the dragon that had appeared at Hwangnyong Temple and advised Chajang to build a ninetiered pagoda at the temple. He said it would prevent Koguryŏ and Paekche from attacking Silla and instead induce them to pay tributes thereby bringing peace to Silla. The second part narrates Chajang's return to Silla in 643 and his meeting with Queen Sŏndŏk where he recounted his encounter with the divine man. Sŏndŏk granted him permission to build a nine-tiered pagoda at Hwangnyong Temple, and the pagoda was completed after years of construction that involved a huge number of people. The last part describes the same story found in the entry on the jade belt, in which a "king of Koryŏ" decided against attacking Silla due to the presence of the three national treasures.

Just as the previous two treasures, the nine-tiered pagoda was also closely related to royal authority. Queen Sŏndŏk was the monarch at the time, and as she was the first female monarch, her authority was being challenged from all sides. The entry in the Memorabilia on the pagoda describes the divine man as saying, "A woman has become the leader of your country, and there is virtue but no dignity." The words of Emperor Taizong of Tang to the envoy from Silla who requested help ${ }^{11}$ also show that the base of political support for Sŏndŏk was weak at the time. Chajang returned to Silla during the reign of Sŏndŏk and explained through the story of the divine man that Hwangnyong Temple was the place where the dharma protector dragon (hobŏpnyong, 護法龍) resided and that building a nine-tiered pagoda would bring the Nine Tribes (kuhan, 九韓) to pay tribute to Silla. The construction of the nine-tiered pagoda

11 Samguk sagi 5, Annals of Silla 5, September of the 12th year (643) of Queen Sŏndŏk. 
was an attempt to bring together Silla in order to protect Buddhism and emphasize the role of Sŏndŏk as the ruler and protector of the nation.

Then what do the three national treasures of Silla signify? With the introduction of Buddhism to Silla, the three treasures were considered to signify Buddha, dharma, and monks with the introduction of Buddhism to Silla. ${ }^{12}$ And along the same lines, the general opinion was that the treasures were related to strengthening the power of the royal family in sixth and seventh-century Silla. ${ }^{13}$ Above all, considering that Chinp'yŏng belonged to the sónggol, or the "sacred bone" rank, which was the highest class in Silla and that the jade belt was also called the "sacred king's belt" (sŏngjedae, 聖帝帶) ${ }^{14}$ it seems clear that the jade belt was closely related to the sacred bone rank and furthermore with the royal family of the sacred bone rank.

The three national treasures of Silla then disappeared from the records for a long time until they resurfaced in 920 and 921. In October 920, Kim Ryul traveled to Koryŏ to request for military aid and received a question regarding the three treasures from T'aejo Wang Kŏn. However, Kim was unable to answer T'aejo because he was unaware of the three treasures. Upon his return to Silla in January 921, Kim reported the incident to the king. The king of Silla then asked the government officials about the three treasures but no one knew what they were. After a long search, the king finally found a 90-year-old monk at Hwangnyong Temple who informed the king that the jade belt was stored in the south storage area. Yet even in the storage area, the belt was nowhere to be found. Eventually, the king of Silla conducted a rite and was finally able to find the jade belt. ${ }^{15}$ The three national treasures of Silla reinforced the authority of the sovereigns

12 Chunghwan Chong, "Silla Sŏngool Go," in Yi Hong-jik Paksa Hoigap Kinyom Han-guk Sahak Nonch'ong, ed. Yi Hong-jik Paksa Hoigap Kinyŏm Han-guk Sahak Nonch'ong Gan-haeng Wiwŏnhoe (1969).

13 Kim, "Silla Sambo ŭi Sŏngrip gwa gŭ Ǔiŭi," 63.

14 Koryŏsa (高麗史) 2, Hereditary House 2, May 2 (kyechuk), 937(the 20th year of T'aejo)

15 Samguk sagi 12, January of the 5th year (921) of Kyŏngmyŏng-wang. 
of the sacred bone rank, such as Chinhŭng, Chinp'yŏng, and Sŏndŏk, and gained the status of "National Treasures." In this regard, the three national treasures were of great importance to the monarchs of the sacred bone rank, while remaining inaccessible to the royalties of the chin'gol, or the "true bone" rank, who became the monarchs of Silla starting in the midseventh century after King Munmu. To the monarchs of the true bone rank, which was below the sacred bone rank, the three national treasures signified restriction to their power. ${ }^{16}$

In relation to the nine-tiered pagoda of Hwangnyong Temple, Ch'archubon'gi (刹柱本記), a document from 872 (12th year in the reign of King Kyŏngmun), describes that the "Three Hans became one house; the ruler and the ruled were able to live in comfort thanks to the [construction of the nine-tiered pagoda]." ${ }^{\prime 17}$ The reasoning was based on the notion of causality, as the compiler of Ch'archubon'gi attributed Silla's unification of the three kingdoms and the preservation of peace in unified Silla to the construction of the nine-tiered pagoda of Hwangnyong Temple, which occurred years before 872, when Ch'archubon'gi was written. This record demonstrates the fact that the nine-tiered pagoda of Hwangnyong Temple, which was one of the three national treasures, became symbolic of Silla's achievement - the unification of the three kingdoms. ${ }^{18}$ In this context, the nine-tiered pagoda was the most important of the three national treasures and that the three national treasures were in fact symbolic evidences of the protection the Silla royal family received

16 Chai, "Chŏnsa Okgae wa Hŭk Okdae," 34-42.

17 “Hwangnyongsa Kuchüngtap Ch'archubon'gi”(皇龍寺九層塔刹柱本記), in National Research Institute of Cultural Heritage, http://gsm.nricp.go.kr/_third/user/fra me.jsp?View $=$ search $\&$ No $=4 \&$ ksmno $=2866$.

18 Sang Hyun Kim, "Ilyŏn ŭi Iltong-samhan Insik,"(Ilyeon's Perception of Iltongsamhan) Silla Munhwa (The Journal of the Research Institute for Silla Culture) 38 (2011): 244 ; Inuk Heo, “'Samkungnyusa' Hwangryongsagucheungtap cho ŭi Pyŏnnyŏn Kŏmto,"(Consideration of the Chronology of the section of Hwangryongsagucheungtap from 'Samkungnyusa') Sahak Yonku (The Review of Korean History) 113 (2014): 30. 
from Buddhism. ${ }^{19}$

\section{Miraculous Powers of the "Three National Treasures of Silla" and the Identity of the "King of Koryŏ"}

In sum, the stories of the three national treasures of Silla enhanced the authority of the royal family, strengthened sovereign power, and played a critical role in Silla's unification of the three kingdoms, all the while actively employing Buddhism in the process. One of the major episodes that support this claim is the story about the miraculous powers of the three national treasures, which protected Silla and its royal family. This story appears in the entries titled "Jade Belt Bestowed by the Heavens" and the "Nine-Tiered Pagoda at Hwangnyong Temple" in the Memorabilia.

(1) When the king of Koryŏ was plotting to conquer Silla, he said, "I heard that there were three treasures in Silla that protect the kingdom. What are those three treasures?" [The envoy] replied, "The first treasure is the sixteen-foot bronze Buddha statue at Hwangnyong Temple, the second is the nine-tiered pagoda at the same temple, and the third is King Chinp'yŏng's jade belt bestowed by the heavens." Upon hearing the envoy's reply, the (king of Koryŏ) gave up on his plan. ${ }^{20}$

This story appears in the entry "Jade Belt Bestowed by the Heavens." The story in the "Nine-Tiered Pagoda of Hwangnyong Temple" is nearly

19 The process of sanctifying the royal family through religion is also seen in Chinese history. A few studies on this are as follows. Julia Chin, Mysticism and kingship in China (Cambridge: Cambridge University Press, 1997) ; Andrew Eisenberg, Kingship in Early Medieval China (Boston: Brill, 2008).

20 Memorabilia 1, Ki' 1, the jade belt bestowed by the heavens (ch'onsa okdae), Memorabilia 3, Tapsang 4 nine-tiered pagoda at Hwangnyong Temple (Hwangnyong-sa kuch'üngt'ap). 
the same, except for a few words, which seems to indicate that the story in both entries refers to the same incident. This episode illustrates that the "king of Koryŏ" conspired to attack Silla but decided against it when he confirmed the existence of three treasures that protected Silla. This reveals that the three national treasures possessed of protective nature, and were created to safeguard Silla from foreign attacks.

The identity of the "king of Koryŏ" in this story becomes an issue. Major translations of the Memorabilia of the Three Kingdoms have translated the "king of Koryŏ" as the "king of Koguryŏ." 21 However, some scholars have argued it was Kungye, ${ }^{22}$ while others asserted that the king of Koryŏ, or T'aejo Wang Kŏn, was the one who conspired to attack Silla. ${ }^{23}$ The identity of the "king of Koryŏ" could dramatically change the understanding of the relationship between Silla and Koguryŏ as well as Silla and Koryŏ. In particular, if the king of Koryŏ were found to be T'aejo Wang Kŏn, it would expose a completely different aspect from the general understanding that Wang Kŏn maintained an amicable relationship with Silla since his ascension to the throne. In this paper, I argue that, based on the purpose of the anecdote about the miraculous powers of the three national treasures, the circumstances during the time the anecdote was written, and the records in which the anecdote appears, the king of

21 Memorabilia in the Korean History Database provided by National Institute of Korean History.

22 Chang-woo Hong, "Samguk-yusa ŭi Hu-goguryo Insik,"(Identification of the Later Goguryeo in Samguk-Yusa) Yǒksahak Yongu (Chonnam Historical Review) 62 (2016).

23 Sang Hyun Kim, "Silla Sambo ŭi Sŏngrip gwa gŭ Ǔiŭi,” Dongguk Sahak (The Dongguk Historical Review) 14 (1980): 64-65; Sunyong Chung, "Koryŏ T'aejo ŭi TaeSilladongmaeng Sŏng'rip gwa gŭ Sŏngyŏk,"(The Goryeo Policy toward Silla by King T'aejo: the Background of Parley with King Gyeongmyeong) Han'guk Chungsesa Yŏngu (The Journal of Korean Medieval History) 27 (2009): 140-146; Mi-sun Baek, "Silla Hadae ŭi Sambo,"(Three Treasures in the Later Period of Silla) Sillasa Hakpo 23 (2011): 579-617; Heo, "Pyŏnnyŏn Kŏmto," 30-31; Bok-Soon Kim, "Koryŏ sidae Kyŏngju wa Silla Munhwa,"(Gyeongju and culture of Silla during the Goryeo Dynasty) Kyung-ju Sahak 39-40 (2015): 35-37. 
Koryŏ was, in fact, the king of Koguryŏ.

First, the records indicate that the three national treasures of Silla were created in the late sixth and mid-seventh centuries, when competition between Silla and Koguryŏ had been intensifying. From the reign of King Chinhŭng to the reign of Queen Sŏndŏk, Silla and Koguryŏ had been waging a war against each other. This means that there was not one certain king of Koguryo who was particularly problematic in the relationship between Silla and Koguryŏ, but rather the existence of Koguryŏ itself and Koguryŏ's policy on Silla were problematic. Therefore, the miraculous and protective powers of the treasures become significant solely in the context that their powers deterred Koguryŏ from attacking Silla and helped Silla fend off Koguryŏ. It was unnecessary for the records to specify whether the king was King Pojang or some other monarch of Koguryŏ. While the miraculous powers of the treasures would gain more credibility with more specific historical background, it was by no means required for the purpose of the Memorabilia.

Now, let us bear this in mind and consider the following cases. First, some people, such as Chung Sunyong, have asserted that the king of Koryŏ is in fact T'aejo Wang Kŏn. Chung grounded his argument on the fact that, at the time of the founding, Koryŏ adopted an aggressive policy and actively and preemptively attempted to launch an attack on Silla. ${ }^{24}$ Scholars such as Chung explained that T'aejo had been actively employing anti-Silla policies to annex Silla, and that was the reason he asked

24 Chung, "Koryŏ T'aejo ŭi TaeSilladongmaeng," 140-146; Sunyong Chung, "Koryŏ T'aejo ŭi TaeSilladongmaeng Chegyŏl gwa gŭ Unyŏng,"(Alliance Agreement with Silla and Its Operation by King T'aejo of Goryeo Dynasty: Centered on Negotiation with Kings Gyeongmyeong Gyeongae of Silla Dynasty) Han'guk Kodaesa T'amgu (Sogang Journal of Early Korean History) 3 (2009): 138. In addition, Chung thought that King Pojang and Kungye could not be 'King Koryŏ' for two reasons: One is that the Koguryo continued to attack Silla in the 650s, unlike the legend, and the other was that in 907 when Kungye had stopped anti-Silla policy, he changed country name to Majin instead of Koryŏ. As a result, he claims that 'King Koryo' is actually possible only by Wang Kŏn. 
Kim Ryul about the existence of the three national treasures, which were said to protect Silla.

However, there are two major reasons that raise doubt about the identification of the king of Koryŏ as T'aejo Wang Kŏn. The first is the circumstances of the time. Immediately upon his ascension to the throne, T'aejo Wang Kŏn took measures to restore the bureaucratic system based on Silla's system of ranks and government posts, which had been disparaged and changed by Kungye. ${ }^{25}$ Also, T'aejo sent the news of his ascension to the throne with gifts to the leaders of various kingdoms in Korea, including Kyŏnhwŏn, of Later Paekche. The records indicate that Kyŏnhwŏn was the only one who did not return the gesture. ${ }^{26}$ Since T'aejo sent an envoy to Later Paekche, I believe he also sent an envoy to Silla. And T'aejo's gesture suggests that he recognized and emphasized the authority of Silla since the founding of Koryŏ and wished to lay a foundation for his rule by establishing a stable and amicable diplomatic relations with Silla. ${ }^{27}$ In this context, it seems that the possibility of T'aejo attempting to launch an attack on Silla was rather low.

The second reason is that the Memorabilia, which contains the records on the Three National Treasures of Silla, had been compiled in the Koryŏ dynasty. It is rather unusual to have the name "Koryŏ" appear in a book that was compiled in the Koryŏ dynasty. In the history of Korea, there were a total of three "Koryǒ" - the first one was founded by Chumong in 37 BCE (often referred to as Koguryŏ); the second was founded by Kungye in 900 (often referred to as Later Koguryŏ); and the third was founded by Wang Kŏn in 918. In the Memorabilia, the Koryŏ that was

25 Koryŏsa 1, Hereditary House 1, June 27 (muchin), 918 (the 1st year of T'aejo).

26 Koryŏsa 1, August 9 (kiyu), 918 (the 1st year of T'aejo).

27 Soo-Jin Moon, "Wang Kŏn ŭi Koryŏ Kŏnkuk gwa Husamguk T'ongil,'(Foundation of Koryŏ Dynasty and Unification of Late Three Kingdoms by Wang Kŏn) Kuksagwan Nonchong 35 (1992): 166; Hyon-Ku Min, "Hanguksa'e it'sŏsŏ Koryŏ ŭi Husamguk T'ongil,'(The Unification of Late Three Kingdoms by Koryŏ Dynasty's in the Korean History) in Koryŏ Chŏngch'isa Ron (Seoul: Korea University Press, 2004), 80. 
founded by Wang Kŏn is referred to as "this dynasty," distinguishing it from Koguryŏ. The following are several examples of such cases: In the entry titled "Nine-Tiered Pagoda of Hwangnyong Temple," the author makes a clear distinction between Silla and Koryŏ in the years after the completion of the pagoda and refers to Koryŏ as "this dynasty." The Memorabilia also contains a remark on the history of Nangnang: Silla referred to itself as Nangnang, and therefore Koryŏ (which was written as "this dynasty") also referred to Silla as Nangnang. ${ }^{28}$ Moreover, references to the reigns of T'aejo and other monarchs of the Koryŏ dynasty in the Memorabilia have been written as "the sixth year in the reign of the first king T'aejo of this dynasty (本朝太祖即位六年). ${ }^{29}$ Based on these examples, Koryŏ in the Samguk yusa almost always refers to Koguryŏ. ${ }^{30}$

(2) In the History of the Three Kingdoms, there is a record that "in the Muin year (678) in the reign of Gaozong of Tang, descendants of the people of Koryŏ gathered together in the north, below Mount Taebaek, and called their country 'Parhae.",31

(3) In the Biography of Buddhist Monks, a monk called Podŏk was named Chibŏp, and he was from the Previous Koryŏ (chŏn Koryŏ), meaning Yonggang-hyŏn of Koguryǒ...and he lived all his life in Pyŏngyang. ${ }^{32}$

Entry (2) explains the founding of Parhae by a group of people described as the "descendants of the people of Koryŏ." Chronologically, Parhae was established after the fall of Koguryŏ. Therefore, it is clear that "Koryŏ" actually refers to Koguryŏ. Entry (3) is part of the records on a Buddhist temple called Yŏngt'ap Temple in Pyŏngyang. The record

28 Memorabilia 1, Ki'i 1, Nakrang-kuk.

29 Memorabilia 3, Tapsang 4, Chŏnhu sojangsari.

30 Hong, "Hu-goguryo Insik," 109.

31 Memorabilia 1, Ki’i 1, Malgal \& Parhae

32 Memorabilia 3, Tapsang 4, Koryŏ yŏngtapsa. 
shows that a Buddhist monk called Podŏk lived in Pyŏngyang in "Previous Koryŏ." The term "Previous Koryŏ" mentioned in this record was used to distinguish it from the Koryo dynasty, ${ }^{33}$ and the term refers to Koguryŏ as well. Besides these cases, "Koryŏ" is mentioned numerous times in the Memorabilia. However, with the exception of one record in the chapter titled "Kings' Chronology" (wangnyŏk, 王曆), where "Koryŏ" is used to refer to Kungye's Later Koryŏ, it always refers to Koguryŏ. This is different from the fact that the Koryŏ dynasty was referred to as "this dynasty."

Furthermore, it would have been inconceivable for Iryŏn, the compiler of the Memorabilia, to refer to T'aejo of the Koryŏ dynasty as the "king of Koryŏ." In fact, Wang Kŏn, the first king of the Koryŏ dynasty, is always referred to by his posthumous title T'aejo throughout the Memorabilia. In my research, I found eleven instances in which Wang Kŏn is featured in the Memorabilia. In all of those cases, Wang Kŏn was referred to as "Our T'aejo" or "T'aejo of this country." 34 Besides T'aejo, other kings of Koryŏ were also not simply referred to as the king of Koryŏ, but rather by their posthumous titles, such as Munjong and Yejong. ${ }^{35}$ In the process of compiling the Memorabilia, Iryŏn worked hard to use credible sources, made an effort to provide a logical and objective narrative, and even attached compiler's notes in parts that could caused confusion for the reader or require explanation, using phrases such as "or in other words" and "In my opinion..." 36 Therefore the fact that there were no notes on the "king of Koryŏ" seems to suggest that the compiler was certain that the use of

33 The expression 'Hu(means later) Koryŏ' comes only from the meaning of the country founded by Kungye in the chapter "Kings' Chronology" of the Samguk yusa. Therefore, 'previous or later Koryŏ' refers to the country founded by Chumong or Kungye, and does not mean Wang Kŏn's consideration.

34 Hong, "Hu-goguryo Insik," 109.

35 Memorabilia 2, Ki'i 2, Karak'kukgi.

36 Sang Hyun Kim, “Samgukyusa ŭi Yŏksa Pangbŏpronjŏk Koch'al,”(Historical Methodology of the Memorabilia of the Three Kingdoms) Tongyanghak (The Oriental Studies) 23 (1993): 11-18. 
this term would cause no confusion for the reader as to the identity of the "king of Koryŏ." In conclusion, there is no chance that Iryŏn would have described T'aejo Wang Kŏn as simply the "king of Koryǒ."

Then who is this "king of Koryŏ" mentioned in the stories of the three national treasures of Silla? When we rule out Wang Kŏn, the possibilities are narrowed down to Kungye or a king of Koguryŏ. I believe that it is more likely to be a king of Koguryŏ rather than Kungye. It is well known that Kungye abhorred Silla and wanted it destroyed. However, considering that the three treasures were created in the sixth and seventh centuries, much earlier than Kungye's time, it seems rather implausible to argue that Kungye is the "king of Koryŏ" in the Memorabilia.

As examined in the first section of this paper, all of the three national treasures were created in Silla between the reigns of King Chinhŭng and Queen Sŏndŏk. The stories about the miraculous powers of the nine-tiered pagoda and the jade belt are basically the same, and through these stories the three treasures, including the sixteen-foot bronze Buddha statue, became known as the three national treasures that safeguard Silla. However, despite the existence of the three treasures, records from the eighth century, after members of the royal family from the true bone rank became the monarchs of Silla, also mention the emergence of a legendary flute (manp'asikchŏk) that defeated the enemy when played, as well as the story of a sacred dragon which gave King Sinmun a black jade belt. ${ }^{37}$ instead of the three national treasures, the flute and the black jade belt became established as the treasures that safeguard Silla under the rule of monarchs from the true bone rank. ${ }^{38}$ In other words, the three national treasures were known for their protective nature from the reign of Queen Sŏndŏk, when all three national treasures came into existence, to the reign of King Sinmun before the appearance of the legendary flute. Considering these circumstances, it would be unreasonable to argue that the stories of

37 Memorabilia 2, Ki'i 2, Manpasikjŏk.

38 Chai, "Chŏnsa Okgae wa Hŭk Okdae,” 34-42. 
miraculous powers of the three treasures lasted until after mid-Silla. ${ }^{39}$

Then which king of Koguryŏ is the "king of Koryŏ" in the Memorabil$i a$ ? Is it King Pojang, who ruled Koguryŏ during the reign of Sŏndŏk of Silla when the three national treasures became known for their miraculous powers? Pojang may be a possible candidate. However, as I mentioned before, the stories were only used to demonstrate the fact that the three national treasures have miraculous powers, rather than to discuss a particular king. The context in which a king of Koguryŏ was mentioned was all that was necessary for the stories. While it is possible that the "king of Koguryŏ" in the Memorabilia is Pojang, the specific identity of the king of is not important for the purpose of the stories. The records about the miraculous powers of the three national treasures need to be understood not for the historical purpose of recording that a certain king wanted to attack Silla but for the purpose of illustrating the miraculous powers of the three national treasures that prevented even Koguryŏ from waging a war against Silla.

In sum, the three national treasures of Silla have become known as treasures that safeguard Silla during the reign of Sŏndŏk when all the three treasures came to be in existence. Through the story about the existence of the three treasures deterring the "king of Koryŏ" from launching an attack on Silla, the three treasures became established as treasures that protect Silla. In this context, the "king of Koryŏ" who appears in the Memorabilia needs to be understood not as T'aejo Wang Kŏn, the founder of the Koryŏ dynasty, but as a "king of Koguryǒ.",40

39 Of course, there is a opinion that the king of 'Koryŏ' claims to be Kungye (Hong, “Hu-goguryo Insik.”). Hong translated “後高麗王' from the original text into a compound noun, 'king of later koryǒ', which is different from my translation of 'in the later, Koryo king...' However, in the Samguk yusa, Kungye is not recorded as a king but written only by his name. And if the time of this legend is the reigning period of Kungye, the formation of 'Sambo' itself should also come down at this time. The legend can not go down to the 10th century as long as the formation of 'Sambo' is recognized as 7th century.

40 It is important that 'Sambo' were treasures of the sacred-bone sŏng'gol. For this 


\section{The Transfer of the "Three National Treasures of Silla" and its Significance}

Then why did T'aejo Wang Kŏn show interest in the three national treasures of Silla, and what exactly happened in the process in which the three national treasures were transferred to Koryŏ?

First, Wang Kŏn ousted Kungye and ascended the throne himself on the premise that he would address and rectify the chaotic state of Samhan (three kingdoms, meaning Silla, Later Paekche, and Koryŏ). As Hong Yu and others crowned Wang Kŏn king, they pointed out that over 20 years passed since Kungye founded a nation and designated a capital city, yet he was unable to unify the divided Samhan. ${ }^{41}$ They argued that the most important task of the time was to address the division of Samhan. However, since Kungye showed no progress in this task and also had not ruled the nation appropriately, they asserted that Kungye should step down. Although this might have been nothing more than a nominal justification for Wang Kŏn's rise to power, the unification of Samhan-or Samhan irt'ong — once again surfaced as a problem that needed to be addressed.

Wang Kŏn's awareness of and goal for the unification of Samhan are also described in other records. For instance, Ch'oe Chimong once interpreted Wang Kŏn's dream as a good omen that he would later come to rule all of Samhan. ${ }^{42}$ Also, at the time of his surrender to Wang Kŏn, Pak Yŏnggyu, the son-in-law to Kyŏnhwŏn of Later Paekche, also told Wang Kŏn that the latter would become the lord of Samhan. ${ }^{43}$ Moreover, the

reason, at the time of the king of the true bone Chin'gol, 'Sambo' such as the jade belt would have been treasures that the true bone kings could not reach. So, instead of the jade belt, the black jade belt appeared as a new treasure in the period of the true bone kings. I think that this was the reason why the ruling rulers had forgotten the existence of the jade belt in the late Silla period.

41 Koryŏsa 92, The Memoirs 5, Hong Yu.

42 Koryŏsa 92, Ch'oe Chimong.

43 Koryŏsa 92, Pak Yŏnggyu. 
engraving on the tombstone of the Buddhist monk named Tongjin Taesa, recorded in 958, also includes the following information: in the autumn of the third year of the Qingtai Era (936), our T'aejo the Holly Great King personally...brought peace to Samhan and took possession of all surrounding counties and prefectures." ${ }^{, 44}$ These records all demonstrate the fact that Koryŏ unified the three kingdoms (Samhan), signifying that T'aejo aimed or hoped to unify Samhan into one country around the time all three kingdoms were unified under Koryŏ. ${ }^{45}$

With such an aim in mind, T'aejo showed interest in the three national treasures of Silla, as is evidenced by the conversation between T'aejo and Kim Ryul, an envoy from Silla.

(4) In the first month in the spring of the fifth year (in the reign of King Kyŏngmyŏng, 921), Kim Ryul said to the king, "When I visited Koryŏ as an envoy, the king of Koryŏ asked me, 'I heard that there are three treasures in Silla: the sixteen-foot bronze Buddha statue, a nine-tiered pagoda, and a sacred belt. I know that the Buddha statue and the pagoda are still in Silla but do you know if the jade belt is still in Silla?' I was not able to answer his question." 46

44 "Okryongsa Tongchin Taesa Cha'untapbi," in Yǒkchu Namalryŏcho Kŭmsǒkmun, ed. Han'guk Yŏksa Yŏn'guhoe (Seoul: Hyean, 1996): 312.

45 There are many studies on the recognition of the Three Hans(samhan) and the Three Kingdoms (samkuk). However, this article is not a full-scale review on this topic, so I did not strictly distinguish between the samhan and the samkuk. The following studies are referenced on this topic. Yongha Kim, "Irt'ong Samhan ŭi Silsang gwa Ǔisik,"(Reality and Consciousness of Three Hans' Unification) Hankuk Kodaesa Yŏn'gu (The Journal of Korean Ancient History) 59 (2010); Sang Hyun Kim, "Ilyŏn ŭi Iltong-samhan Insik"(Ilyeon's Perception of Iltong-samhan), Silla Munhwa (The Journal of the Research Institute for Silla Culture) 38 (2011); SooTae Kim, "Ilyŏn ŭi Samhan. Samguk Tong'ilron,"(Iryon's Discussion of the Unification of Three Hans/Kingdoms) Soggang Inmun Nonchong (Humanities Journal) 43 (2015).

46 Samguk sagi 12, January, 921 (the 5th year of Kyŏngmyŏng-wang). 
In October 920, Later Paekche advanced to Taeyasŏng (present-day Hapch'ŏn-gun, South Kyŏngsang Province). In response, Silla urgently requested for the help of Koryŏ. Kim Ryul had been sent at the time as an envoy to Koryŏ, which means that the conversation he had with Wang Kŏn mentioned above also occurred in October 920. Silla was in Koryŏ to enlist the help of Koryŏ during the crisis of an attack from Later Paekche. However, T'aejo Wang Kŏn appears in the story as asking Kim about the three national treasures at the meeting. Hwangnyong Temple was still in existence in Kyŏngju at the time, and the nine-tiered pagoda, which had been damaged during the reign of King Kyŏngmun, was repaired at the time. $^{47}$ Therefore it would have been easy for Koryŏ to learn about the existence of the statue and the pagoda in Silla. However, the existence of the sacred belt had not yet been confirmed. Compared to the statue and the pagoda, which were rather sizeable artifacts, the jade belt was relatively easy to keep hidden. This means that T'aejo knew of the existence of the two treasures of Hwangnyong Temple. It seems that he wanted to confirm the existence of all three national treasures of Silla by verifying the existence of the jade belt.

However, Kim Ryul did not know what the "sacred belt" was, and neither did the members of the ruling class of Silla. They were only able to learn that the sacred belt was the jade belt bestowed by the heavens and that it was kept in the south storage area. However, the jade belt was virtually lost, considering that Silla had forgotten not only that the "sacred belt" was the "jade belt bestowed by the heavens" but also the place it was kept hidden. ${ }^{48}$

The reason T'aejo showed interest in the three national treasures of Silla was not because he had been planning on annexing or attacking Silla but because he strove to become the leader of unified Samhan and ulti-

47 Heo Inuk detailed the repair process of the pagoda of Hwangnyong temple from Silla to Koryo (Heo, "Pyŏnnyŏn Kŏmto.")

48 In this regard, I think that T'aejo might want to check whether Silla was dangerous because the 'Sambo' had disappeared or not. 
mately was faced with the task of unifying Samhan, which included Silla.

(5) Later on, T'aejo said to Ch'oe Unng, “In the past, Silla built a nine-tiered pagoda and achieved the unification of the kingdoms. I wish to build a seven-tiered pagoda in Kaegyŏng and a nine-tiered pagoda in Sŏgyŏng to receive support from the Buddha to destroy groups of evil people and unify Samhan into one family. So I hope that you will write a prayer for me to the Buddha." Eventually Ch'oe Ǔng composed a prayer and presented it. ${ }^{49}$

(6) When he was 30, T'aejo had a dream. He saw a golden ninetiered pagoda in the middle of the sea and climbed it. ${ }^{50}$

Entry (5) is an anecdote about T'aejo Wang Kŏn's request to Ch'oe Unng for writing a prayer for the unification of Samhan. In this story, T'aejo explains that Silla was able to achieve unification after building a nine-tiered pagoda, and reveals his intention to also build a seven-tiered pagoda in Kaegyŏng and a nine-tiered one in Sŏgyŏng(the Western Capital) to unify Samhan. The nine-tiered pagoda he mentions in Silla is the nine-tiered pagoda of Hwangnyong Temple, and the number of tiers of this pagoda was a factor in deciding the number of tiers - ("seven" and "nine") - of pagodas to be constructed in Koryŏ. T'aejo's ideas described in this anecdote is also in line with the records found in Ch'archubon'gi mentioned in the first section of this article: the three national treasures of Silla, of which the nine-tiered pagoda of Hwangnyong Temple was the most representative, led to the unification of the three kingdoms.

The story described in entry (6) is about a dream the 30 -year-old Wang Kŏn had of climbing a golden nine-tiered pagoda in the middle of the sea. Since Wang Kŏn was born in 877, the year he turned 30 was 906. This was before Wang Kŏn became king, and he had been serving Kungye at

49 Koryŏsa 92, Ch'oe Ǔng

50 Koryŏsa 1, Introduction on T'aejo. 
this time. The dream was a prophetic one that foretold that Wang Kŏn would become king. The interesting part in this anecdote is the appearance of a golden nine-tiered pagoda. In other words, Wang Kŏn had seen his fate of becoming a ruler of a country with a nine-tiered pagoda in his dreams.

Ultimately, T'aejo became interested in the three national treasures because they were symbolic of the unification of the divided Samhan, and he aspired to become the ruler of unified Samhan.

Since 920, the year King Kyŏngsun of Silla sent Kim Ryul to request military help, Koryŏ and Silla formed and maintained a close relationship, which continued into the reigns of King Kyŏngmyŏng, King Kyŏngae, and King Kyŏngsun. Koryŏ was defeated by Kyŏnhwŏn of Later Paekche in 927 at Kongsan (present-day Taegu) as Kyŏnhwŏn was returning after pressuring King Kyŏngae of Silla to commit suicide. However, in 930, Koryŏ crushed Later Paekche at Koch'ang (present-day Andong) and turned the tide of the war. Consequently, over 30 counties and prefectures in North Kyŏngsang Province, in addition to most areas on the east coast of the Korean Peninsula, spanning from Myŏngju (present-day Kangnŭng, Kangwŏn Province) to Hŭngrye (present-day Ulchin, North Kyŏngsang Province), surrendered to Koryŏ, ${ }^{51}$ significantly increasing Koryŏ’s territories.

Around this time, Kyŏngsun of Silla suggested a meeting with T'aejo twice, once in February 930 and again in February 931. ${ }^{52}$ Accepting the invitation, T'aejo paid a visit to Kyŏngju, the capital of Silla, in February 931. ${ }^{53}$ During T'aejo's visit, Kyŏngsun said Silla as a "small country" to T'aejo, which seems to reflect the circumstances of Silla at the time, as Silla had to depend on support from Koryǒ in order to fend off threats

51 Koryŏsa 1, January 25 (kyŏng'in) and February 1 (ŭlmi), 930 (the 13th year of T'aejo).

52 Koryŏsa 1, February 1 (ŭlmi), 930 (the 13th year of T'aejo), Koryŏsa 2, Hereditary House 2, February 9 (chŏng'yu), 931 (the 14th year of T'aejo).

53 Koryosa 2, February 23 (sinhae), 931 (the 14th year of T'aejo). 
from Later Paekche. The people of Silla, described T'aejo upon the latter's visit to Kyŏngju to be "like a parent," 54 which shows that they leaned in favor of Koryŏ.

Finally, Silla decided to surrender to Koryŏ in 935. Around October of the same year, Kyŏngsun of Silla realized that Silla was weak and would be unable to preserve itself. After discussions with government officials, Kyŏngsun sent a document detailing his decision to Koryŏ. ${ }^{55}$ And on November 3, Kyŏngsun left Kyŏngju with the officials of Silla and arrived at Kaegyŏng on the next day to meet with T'aejo. ${ }^{56}$ In December, T'aejo expressed his intention to accept Silla's surrender and officially annexed Silla after receiving an audience ritual from Kyŏngsun. ${ }^{57}$

In this way, T'aejo came to annex Kyŏngju and the rest of Silla's territory as well as her people after Silla's surrender, including the three national treasures of Silla. The records indicate Kyŏngsun's trip to Koryŏ consisted of beautifully decorated carriages and horses lined up for 12 kilometers. ${ }^{58}$ Although this might have been an exaggeration, it seems likely that Silla handed over her treasures to Koryŏ. Naturally, there were immovable treasures such as Hwangnyong Temple, but with Silla's surrender to Koryŏ, the sixteen-foot bronze Buddha statue and the ninetiered pagoda also became part of T'aejo's possession.

The last of the three treasures - the jade belt bestowed by the heavens-was given to T'aejo in 937.

(7) On May 2, the summer of the 20th year (in the reign of T'aejo, 937), Kim Pu presented a rectangular belt engraved with gold and made of jade. Its length was $10 \mathrm{pal}$ (圍), and it consisted of 62 pieces. Silla had cherished the belt as a treasure for almost

54 Samguk sagi 12, Februay, 931 (the 5th year of Kyongsunwang).

55 Samguk sagi 12, October, 935 (the 9th year of Kyongsunwang).

56 Koryosa 2, November 3 (kap'o) and 12 (gyemyo), 935 (the 18th year of T'aejo).

57 Koryŏsa 2, December 12 (imsin), 935 (the 18th year of T'aejo).

58 Ibid. 
400 years, and in the world it was called "sŏngjedae" (sacred king's belt). The king received the belt and ordered Ikhwŏn, a civil official, to keep the belt at the Mulchangsŏng, the government office in charge of storing royal goods. ${ }^{59}$

In 937, Kim Pu, or King Kyŏngsun of Silla, handed over the jade belt known in Silla as the sacred king's belt, and T'aejo ordered to have it stored at the government department in charge of storing royal goods. This means that a year and a half had passed since Silla's surrender to Koryŏ before Silla handed over the jade belt, one of the three national treasures. As the two treasures located in Hwangnyong Temple had become Koryŏ's treasures due to the annexation of Silla, the transfer of the jade belt meant that Koryŏ was now in possession of all three national treasures of Silla.

The transfer of the treasures seems to have been rather largely influenced by Koryŏ's unification of the Later Three Kingdoms the previous year. T'aejo waged a war against Shin'gŏm of Later Paekche, who surrendered in September 936. ${ }^{60}$ When T'aejo returned to Kaegyŏng, a celebratory ceremony was held at Uibong Pavilion, organized and attended by all government officials. ${ }^{61}$ This marked the end of Later Paekche.

T'aejo's goal of unifying Samhan - the unification of the Later Three Kingdoms - was achieved in 936. About eight months later, in 937, Kim $\mathrm{Pu}$ handed over the jade belt to T'aejo, and T'aejo came to possess all three national treasures of Silla. The progression of these events signifies the close relationship between the three national treasures of Silla and the unification of Samhan. Kim Pu's presentation of the jade belt to T'aejo was not merely a gift but rather an event that signified the transfer of the Mandate of Heaven to from Silla to Koryŏ. Furthermore this occurrence confirmed T'aejo Wang Kŏn as the legitimate successor to Silla.

59 Koryŏsa 2, May 2(gyechuk), 937(the 20th year of T'aejo).

60 Koryŏsa 2, September 8(kap'o), 936(the 19th year of T'aejo).

61 Koryŏsa 2, September, 936(the 19th year of T'aejo). 
(8) Our T'aejo studied how to get along with his neighboring countries from the beginning. So he knew early on about the excellent culture of Silla, and then he married the royal family of Silla. Thus he rewarded Silla's righteousness. (Divided) families and countries have come together as one, and the ruler and the ruled became the people of the unified Samhan. ${ }^{62}$

The above is an excerpt from the "Document on the Appointment of Sangbo (honorary title meaning, one to be admired and respected as a father)," through which Kim Pu became invested as sangbo in 975. The part cited shows the reason $\mathrm{Kim} \mathrm{Pu}$ was named as sangbo, and it mentions Koryŏ's unification of the Later Three Kingdoms. This seems to suggest that Kim Pu's surrender was believed to have significantly contributed to the unification of the Later Three Kingdoms. In other words, Silla's surrender enabled Koryŏ to unify the three nations, bringing Samhan together as one nation.

In sum, T'aejo inherited and received the three national treasures of Silla through the Silla's surrender in 935 and the transfer of the jade belt in 937. In 936, T'aejo achieved the unification of the Later Three Kingdoms - "Samhan irt'ong." Silla contributed to the process of Koryŏ's unification of the three nations, and these treasures were not only presents but also evidences of Silla's contribution to the process of Koryŏ's unification of Samhan.

\section{Conclusion}

This paper attempted to explore the significance of the three national treasures of Silla in the history of Koryo by examining the meaning of the treasures and the processes in which they were transferred to Koryŏ. In this process, I also analyzed the controversial identity of the "king of

62 Memorabilia 2, Ki’i 2, Kim Pu Taewang. 


\section{Koryŏ."}

In October 920, T'aejo Wang Kŏn of Koryŏ asked Kim Ryul, an envoy from Silla, about the three national treasures of Silla: "I heard that there are three treasures in Silla - a sixteen-foot bronze Buddha statue and a nine-tiered pagoda of Hwangnyong Temple, and a sacred belt. I know the bronze Buddha statue and the nine-tiered pagoda are still there, but what about the sacred belt?" This conversation revealed that there were three treasures in Silla - the three national treasures of Silla: the sixteen-foot bronze Buddha statue from the time of King Chinhŭng; the jade belt bestowed by the heavens from the time of King Chinp'yŏng; and the ninetiered pagoda of Hwangnyong Temple from the time of Queen Sŏndŏk. Based on Buddhism, the three national treasures of Silla were built or emerged under the leadership of monarchs of the sacred bone rank. Moreover, these three treasures came to occupy the status of national treasures that protect the nation, as the mere existence of the treasures deterred the "king of Koryǒ" from pursuing his plan to attack Silla. Through this, the monarchs of the sacred bone rank were able to strengthen their authority and enhance their status.

The stories that demonstrate the miraculous powers of the three national treasures, which prevented the "king of Koryŏ" from launching an attack on Silla, appear in the legends of the nine-tiered pagoda of Hwangnyong Temple and of the jade belt. And it seems correct to understand that the "king of Koryǒ" mentioned in these stories is a "king of Koguryŏ" rather than Wang Kŏn, the founder of the Koryŏ dynasty. Above all, it is important to take into consideration the fact that the $\mathrm{Me}$ morabilia was compiled in the Koryŏ dynasty. In the Memorabilia, Koryŏ is consistently referred to as "this dynasty" and Wang Kŏn as "T'aejo." Such circumstances eliminate the possibility that T'aejo would have been referred to as simply the "king of Koryŏ."

T'aejo Wang Kŏn, who was aware of the need for and had the will to unify the then-divided three kingdoms, or Samhan, showed interest in the three national treasures of Silla, which were the symbols of Silla's unification. This was the reason he asked about the existence of the three 
treasures to Kim Ryul in 920. Then in 935 and 937, all three treasures were handed over to Wang Kŏn: the Buddha statue and the pagoda, after Silla's surrender; the jade belt, through Kim Pu's presentation to T'aejo. In 936, between Silla's surrender and Kim Pu's presentation of the belt, T'aejo was able to unify the Later Three Kingdoms and achieve the "unification of Samhan." In sum, the transfer of 'the treasures' is the 'gift' of Silla, which means that Koryo inherited the legitimacy of Silla through the achievement of the unification of the Three Kingdoms.

\section{References}

\section{Primary Sources}

1. Koryǒsa (高麗史, History of Koryŏ)

2. Samguk sagi (三國史記, History of the Three Kingdoms)

3. Samguk yusa (三國遺事, Memorabilia of the Three Kingdoms)

4. National Research Institute of Cultural Heritage (한국금석문 종합영상정보시스템 http://gsm.nricp.go.kr/_third/user/main.jsp)

\section{Secondary Sources}

5. Baek, Mi-sun. "Silla Hadae ŭi Sambo"(Three Treasures in the Later Period of Silla). Sillasa Hakpo 23 (2011).

6. Buswell Jr., Robert E. ed. Currents and Countcurrents: Korean Influences on the East Asian Buddhist Traditions. Honolulu: University of Hawai'i, 1993.

7. Buswell Jr., Robert E. "Korean Buddhist Thought in East Asian Context." Bulgyo Hakbo 60, 2011.

8. Chai, Miha. "Chŏnsa Okgae wa Hŭk Okdae." Kyung Hee Sahak (The Historical Review of Kyung Hee University) 24 (2006).

9. Chong, Chunghwan. "Silla Sŏnggol Go.” In Yi Hong-jik Paksa Hoigap Kinyom Han-guk Sahak Nonch'ong, ed. Yi Hong-jik Paksa Hoigap Kinyŏm Han-guk Sahak Nonch'ong Gan-haeng Wiwŏnhoe, 
1969.

10. Chung, Sunyong. “Koryŏ T’aejo ŭi TaeSilladongmaeng Sŏng'rip gwa gŭ Sŏnggyŏk” (The Goryeo Policy toward Silla by King T'aejo: the Background of Parley with King Gyeongmyeong). Han'guk Chungsesa Yŏngu (The Journal of Korean Medieval History) 27 (2009).

11. Chung Sunyong. “Koryŏ T’aejo ŭi TaeSilladongmaeng Chegyŏl gwa gŭ Unyŏng" (Alliance Agreement with Silla and Its Operation by King T'aejo of Goryeo Dynasty: Centered on Negotiation with Kings Gyeongmyeong Gyeongae of Silla Dynasty). Han'guk Kodaesa T'amgu (Sogang Journal of Early Korean History) 3 (2009).

12. Eisenberg, Andrew. Kingship in Early Medieval China. Boston: Brill, 2008.

13. Heo, Inuk. “'Samkungnyusa' Hwangryongsagucheungtap cho ŭi Pyŏnnyŏn Kŏmto" (Consideration of the Chronology of the section of Hwangryongsagucheungtap from 'Samkungnyusa'). Sahak Yonku (The Review of Korean History) 113 (2014).

14. Hong, Chang-woo. "Samguk-yusa ŭi Hu-goguryo Insik" (Identification of the Later Goguryeo in Samguk-Yusa). Yŏksahak Yongu (Chonnam Historical Review) 62, 2016.

15. Joo, Ryan Bongseok. "Buddhism in Korean History." In The Wiley Blackwell Companion to East and Inner Asian Buddhism, edited by Mario Poceski. Chicester: Wiley Blackwell, 2014.

16. Kim, Bok-Soon. "Koryŏ sidae Kyŏngju wa Silla Munhwa" (Gyeongju and culture of Silla during the Goryeo Dynasty). Kyungju Sahak 39.40, 2015.

17. Kim, Le-na. "Hwangyongsa ŭi Changyukjonsang gwa Silla ŭi A'yukwangsang-gye Bulsang" (The Lost Hwangyong-sa Statue of a Buddha Made after the King Asoka Image). Chin-tan Hakpo 46.47 (1979).

18. Kim, Sang Hyun. "Silla Sambo ŭi Sŏngrip gwa gŭ Ǔiŭi." Dongguk Sahak (The Dongguk Historical Review) 14 (1980).

19. Kim, Sang Hyun. "Samgukyusa ŭi Yŏksa Pangbŏpronjŏk Koch'al" 
(Historical Methodology of the Memorabilia of the Three Kingdoms). Tongyanghak (The Oriental Studies) 23 (1993).

20. Kim, Sang Hyun. "Ilyŏn ŭi Iltong-samhan Insik" (Ilyeon's Perception of Iltong-samhan). Silla Munhwa (The Journal of the Research Institute for Silla Culture) 38 (2011).

21. Kim, Soo-Tae. "Ilyŏn ŭi Samhan-Samguk Tong'ilron” (Iryon's Discussion of the Unification of Three Hans/Kingdoms). Sogang Inmun Nonchong (Humanities Journal) 43 (2015).

22. Kim, Yongha. "Irt'ong Samhan ŭi Silsang gwa Ǔisik" (Reality and Consciousness of Three Hans' Unification). Hankuk Kodaesa Yŏn'gu (The Journal of Korean Ancient History) 59 (2010).

23. Min, Hyon-Ku. "Han'guksa'e it'sŏsŏ Koryŏ ŭi Husamguk T'ongil" (The Unification of Late Three Kingdoms by Koryŏ Dynasty in the Korean History). In Koryŏ Chŏngch'isa Ron. Seoul: Korea University Press, 2004.

24. Moon, Soo-Jin. "Wang Kŏn ŭi Koryŏ Kŏnkuk gwa Husamguk T'ongil" (Foundation of Koryŏ Dynasty and Unification of Late Three Kingdoms by Wang Kŏn). Kuksagwan Nonchong 35 (1992).

25. Vermeersch, Sem. "Representation of the Ruler in Buddhist Inscriptions of Early Koryo." Korean Studies 26-2 (2002).

26. Vermeersch, Sem. The Power of the Buddhas: The Politics of Buddhism during the Koryo Dynasty. Cambridge: Harvard University Asia Center, 2008. 


\section{The “Three National Treasures of Silla (新羅三寶)” and Their Transfer: The Symbol of the Unification of the Koryŏ Dynasty}

This paper explores the significance of the three national treasures of Silla (Silla sambo) in the history of Koryŏ through analyzing the significance of the Three National Treasures of Silla.

There are the three national in Silla - a sixteen-foot bronze Buddha statue and a nine-tiered pagoda at Hwangnyong Temple, and the jade belt bestowed by the heavens. These are made from the time of King Chinhŭng to the time of Queen Sŏndŏk. Moreover, these treasures came to occupy the status of treasures that protect the nation, as the mere existence of the treasures was able to persuade the "king of Koryŏ" to abandon his plan to attach Silla. As a result, the treasures were made by the kings of the "sacred bone" sŏng'gol with the Buddhist background, and again, the treasures added to power and authority to the "sacred bone" sŏng'gol family, so the treasure 'Sambo' became a symbol of the nation.

The stories that demonstrate the miraculous powers of the three national treasures of Silla appear in the legends of the nine-tiered pagoda of Hwangnyong Temple and of the jade belt. And it is correct to understand that the "king of Koryŏ" mentioned in these stories is a "king of Koguryŏ" rather than Wang Kŏn, the founder of the Koryŏ dynasty. Above all, it is important to take into consideration the fact that the Memorabilia of the Three Kingdoms was compiled in the Koryŏ dynasty. Therefore in the Memorabilia of the Three Kingdoms, Koryŏ is consistently referred to as "this dynasty" and Wang Kŏn as "T'aejo." Such circumstances eliminate the possibility that T'aejo would have been referred to as 
simply the "king of Koryǒ."

T'aejo Wang Kŏn, who was aware of the need for and had the will to unify the then-divided three kingdoms, or Samhan, showed interest in the three treasures of Silla. Then in 935 and 937, the three treasures were handed over to Wang Kŏn after Silla's surrender and through Kim Pu's presentation of the jade belt to T'aejo. And in 936, T'aejo achieved the "unification of Samhan." In the end, the transfer of 'the treasures' is the 'gift' of Silla, which means that Koryŏ inherited the legitimacy of Silla through the achievement of the unification of the Three Kingdoms.

Keywords: Three National Treasures of Silla, jade belt bestowed by the heavens, sixteen-foot bronze Buddha statue, nine-tiered pagoda at Hwangnyong Temple, King Kyŏngsun, T’aejo Wang Kŏn, historical legitimacy 


\section{〈국문 초록〉}

\section{태조 왕건과 新羅三寶, 그리고 고려의 후삼국통일}

김보광 (대전대 강사)

이 글에서 필자는 '신라삼보'가 지니는 의미와 그것이 고려로 전달되는 과정을 통해 고려사에서 '신라삼보'가 갖는 의미를 탐색하였다.

신라의 세 보물, 곧 ‘新羅三寶’는 황룡사 장육존상과 9층탑, 천사옥대라는 세 보물은 진훙왕에서 선덕여왕에 이르는 시기에 성립하였다. 그리고 그 존재만으로 '고려왕'의 신라 침공을 단념하게 만들 만큼 護國 보물이라는 위상을 차지하였다. 곧 '신라삼보'는 불교를 배경으로, 중고기의 성골 왕실이 주도하에 건립, 조성되었 고, 결과적으로 성골 왕실은 '삼보'를 통해 왕실의 권위와 왕권의 강화를 상징화 하였다.

하지만 분열된 삼한을 통일하겠다는 의지와 인식을 지닌 태조 왕건은 920 년에 신라 사신 김률에게 그 존재를 물어보았을 만큼 신라의 상징인 '신라삼보'에 관심 을 가졌다. 935년의 신라 항복과 937년 김부의 진상이라는 두 차례에 걸쳐 '신라 삼보'는 차례로 태조에게 계승, 전달되었다. 그 사이인 936년에 태조는 후삼국의 통일, 곧 '삼한의 일통'을 달성하였다. 결국 '신라삼보'의 전달은 고려의 삼국통일 이라는 업적을 통해 고려가 신라의 정통성과 정당성을 이어받았음을 의미하는 증 거라 하겠다.

주제어: 신라삼보(新羅三寶), 천사옥대(天賜玉帶), 장육존상(丈六尊像), 황룡사9 층탑, 경순왕, 태조 왕건, 역사적 정통성 
